\title{
Expression of estrogen receptor beta correlates with adverse prognosis in resected pancreatic adenocarcinoma
}

Hendrik Seeliger ${ }^{1,3^{*}}$ (D) loannis Pozios ${ }^{1,3}$, Gerald Assmann², Yue Zhao ${ }^{3,4}$, Mario H. Müller ${ }^{1,5}$, Thomas Knösel2 Martin E. Kreis ${ }^{1}$ and Christiane J. Bruns s.4 $^{3,4}$

\begin{abstract}
Background: The relevance of estrogen receptor (ER) expression in pancreatic ductal adenocarcinoma (PDAC) is largely unknown. Clinical trials targeting ER with selective estrogen receptor modulators in pancreatic cancer did not show any benefit. Here, we analyze the impact of recently characterized ER isoform beta on survival in a cohort of patients with resected PDAC.

Methods: Eighty-four patients having undergone pancreatic resection for PDAC at a single institution were identified. Tissue microarrays were constructed of archival tumor specimens. The expression of ER beta was determined by immunohistochemistry and quantified by a system established for estrogen receptor expression in breast cancer. ER beta expression was then correlated with clinicopathological parameters, and univariate and multivariate survival analyses were performed.
\end{abstract}

Results: Nuclear expression of ER beta was found in 31\% of tumors. No significant correlation was found between ER beta expression and TNM status, tumor grade, age or sex. Univariate analysis revealed nodal metastasis and the expression of ER beta as factors correlating with a shorter overall survival and disease free survival. When comparing ER beta expression in patients surviving more than 24 months with those who died from the tumor within 12 or 24 months, respectively, a significantly lower ER beta expression was found in the long term survivors. In multivariate analysis, ER beta expression was demonstrated to be an independent predictor of shorter overall survival.

Conclusions: In resected PDAC, expression of ER beta seems to correlate with poor prognosis. These data may help to identify patients who may benefit from additional systemic therapy including selective estrogen receptor modulators.

Keywords: Pancreatic ductal adenocarcinoma, Pancreatic cancer, Estrogen receptor beta, Prognosis, Survival analysis, Tissue microarray

\section{Background}

Pancreatic ductal adenocarcinoma (PDAC) is among the leading causes of cancer-related mortality in western countries [1]. In the last decade, overall survival improved only marginally. To date, standard therapeutic regimens consist of surgery, cytotoxic chemotherapy,

\footnotetext{
* Correspondence: hendrik.seeliger@charite.de

'Department of General, Visceral and Vascular Surgery, Campus Benjamin Franklin, Charité Universitätsmedizin Berlin, corporate member of Freie Universität Berlin, Humboldt-Universität zu Berlin, and Berlin Institute of Health, D-12200 Berlin, Germany

${ }^{3}$ Department of General, Visceral and Transplantation Surgery, Hospital of the University of Munich, D-81377 Munich, Germany

Full list of author information is available at the end of the article
}

irradiation, or a combination $[2,3]$ and result in an overall 5 year survival of less than $10 \%$. More recently, newer agents targeted against molecular determinants of cancer cells or tumor vessels, or both, have been tested in clinical trials to expand the therapeutic armamentarium $[4,5]$. When characterizing molecular targets for potential prognostic and therapeutic use, differences in the sex distribution have led to the investigation of the role of estrogen receptors (ER) in the development and progression of pancreatic cancer and other malignancies [6-11]. Most early trials with the selective estrogen receptor modulator tamoxifen in PDAC yielded only a moderate survival benefit while showing an acceptable

(c) The Author(s). 2018 Open Access This article is distributed under the terms of the Creative Commons Attribution 4.0 International License (http://creativecommons.org/licenses/by/4.0/), which permits unrestricted use, distribution, and reproduction in any medium, provided you give appropriate credit to the original author(s) and the source, provide a link to the Creative Commons license, and indicate if changes were made. The Creative Commons Public Domain Dedication waiver (http://creativecommons.org/publicdomain/zero/1.0/) applies to the data made available in this article, unless otherwise stated. 
safety profile [12-14]. This concept of inhibition of ER mediated effects however did not take into account recently reported existence of differential signaling of ER isoforms $\mathrm{ER} \alpha$ and $\mathrm{ER} \beta$ [15-17].

Human ER $\beta$ was cloned in 1996 for the first time and subsequently was shown to have a ligand binding specificity and a signaling response to estrogen agonists that is distinct from ER $\alpha$ [15-18]. While ER $\alpha$ was demonstrated to promote tumor growth and angiogenesis in breast cancer and many other solid tumor types, the role of ER $\beta$ is defined much less clearly.

In ER $\alpha$ negative breast cancer specimens, ER $\beta$ was shown to correlate with a higher proliferation index [9]. Furthermore, in breast cancer patients, ER $\beta$ was characterized as a response marker of the selective estrogen receptor modulator tamoxifen in unselected cohorts and in patients negative for $\mathrm{ER} \alpha[19,20]$. In non small cell lung cancer patients results are controversial. While in one study, high ER $\beta$ expression served as a negative prognostic marker and correlated with a worse outcome [21], a metaanalysis failed to find a consistent correlation of ER $\beta$ expression with survival [22]. Beside ER $\beta$-specific effects, ER $\beta$ activation seems to interfere with EGF receptor signaling via an activation of the MAP kinase [10, 23].

While pancreatic cancer cell lines were reported to express $\operatorname{ER} \beta$ [24], there is no consistent information available on the expression of ER $\beta$ in human pancreatic ductal adenocarcinoma specimens and its correlation with histopathological parameters and prognostic consequences [8]. The present study was designed to analyze the influence of ER $\beta$ expression on overall and disease free survival in PDAC. Here, in a cohort of 94 patients having undergone a pancreatic resection, we correlate ER $\beta$ expression in a tissue microarray derived from intraoperative tumor specimens with clinicopathological and survival parameters.

\section{Methods \\ Patients}

We identified 111 consecutive patients from a prospective database of patients operated for ductal pancreatic adenocarcinoma at a single institution. Of these, clinicopathological information and prospectively collected follow up data as well as archived tumor material were available for evaluation in 84 patients. Patients with distant metastases were excluded from the study as well as patients who died within 30 days after resection. Specifically, information on age, sex, date of the primary surgery, perioperative irradiation or chemotherapy, TNM tumor status and grading, date last seen, date of death, cause of death, and date of the first identification of tumor progression were extracted from the original patient charts and a regional tumor registry database. The study was approved by the Ethics Committee of the Hospital of the University of Munich. Due to the retrospective nature of the study, explicit consent was not required.

\section{Tissue microarray construction}

Paraffin embedded archive tissue material of tumor and surrounding normal pancreatic tissue was used to generate tissue microarrays (TMAs) after confirming the histological diagnosis of PDAC by a pathologist blinded for the clinical data.

TMAs were prepared essentially as published before [25]. In brief, the area of interest to be sampled was identified and marked on an areal slide corresponding to each paraffin block. Three tissue core biopsies, each $0.6 \mathrm{~mm}$ in diameter, were punched out of the donor paraffin block and then arrayed in each of the respective recipient TMA blocks using a manual arrayer (Beecher Instruments, Sun Prairie, WI). Edge confusion was ensured by incubating the TMAs at $37^{\circ} \mathrm{C}$ for $30 \mathrm{~min}$. Sections of $2 \mu \mathrm{m}$ thickness were cut onto adhesive glass slides (Super Frost Plus, Menzel, Braunschweig, Germany).

\section{Immunohistochemistry}

Immunohistochemistry for ER $\beta$ was performed using standard technique. Briefly, after deparaffinization and rehydration, slides were blocked with bovine serum albumin. The primary antibody (Rabbit polyclonal to estrogen receptor beta, Abcam, Cambridge, UK), was added in a dilution of 1:200 and incubated overnight at $4{ }^{\circ} \mathrm{C}$. After blocking endogenous peroxidase with $7.5 \%$ hydrogen peroxide, a horseradish-peroxidase conjugated polyclonal goat anti-rabbit secondary antibody (Dako, Hamburg, Germany) was added and incubated for $30 \mathrm{~min}$ at room temperature. Slides were counterstained with hematoxylin.

\section{Histopathological evaluation}

ER $\beta$ expression was quantified analogous to the scoring system proposed by Remmele and Stegner used for ER $\alpha$ in breast cancer [26]. Briefly, staining intensity was scored from 0 (no reaction) to 3 (strong reaction), and the percentage of stained nuclei was scored from 0 (no positive nuclei) to 4 (more than $80 \%$ positive nuclei). The scores of staining intensity and stained nuclei were multiplied, yielding a total core of 0 to 12 . Positive expression of ER $\beta$ was defined as a score of 3 or more. Scoring was performed by two independent pathologists blinded for the clinical data.

\section{Statistical analysis}

Statistical analyses were performed by utilizing IBM SPSS statistics 23 software package (IBM, Armonk, NY). Chi-square tests were applied to test correlation between categorical variables. Survival curves were calculated according to Kaplan-Meier, with differences in survival between 
strata of low and high ER $\beta$ expression and clinicopathological parameters detected by the log-rank test. Multivariate analysis was performed using the Cox proportional hazards model including variables with a $p$ value of less than 0.15 in univariate analyses. A $p$ value of less than 0.05 was considered statistically significant.

\section{Results}

\section{Demographic data}

The study cohort consisted of 84 patients, 41 men and 43 women with a median age of 65.6 years at the time of the operation (range 32-82 years). Demographic and clinicopathological characteristics of the patients are summarized in Table 1. At the time of the analysis, 63 patients $(75.0 \%)$ had died from the tumor, and three more patients had tumor progression.

\section{Expression of ER $\beta$}

A nuclear expression of the ER $\beta$ was detected in 26 PDAC tumor specimens (31.0\%). Representative slides are shown in Fig. 1. No correlation was seen between ER expression

Table 1 Clinicopathological parameters of 84 patients with resected pancreatic ductal adenocarcinoma

\begin{tabular}{|c|c|c|c|}
\hline Variable & & $n$ & $\%$ \\
\hline \multirow[t]{2}{*}{ Sex } & female & 43 & 51.2 \\
\hline & male & 41 & 48.8 \\
\hline \multirow[t]{2}{*}{ Age } & $\leq 60$ years & 24 & 28.6 \\
\hline & $>60$ years & 60 & 71.4 \\
\hline \multirow[t]{4}{*}{ Type of operation } & PD & 35 & 41.7 \\
\hline & PPPD & 34 & 40.5 \\
\hline & Distal pancreatectomy & 10 & 11.9 \\
\hline & $\mathrm{TP}$ & 5 & 6.0 \\
\hline \multirow[t]{4}{*}{ T status } & $\mathrm{T} 1$ & 1 & 1.2 \\
\hline & $\mathrm{T} 2$ & 10 & 11.9 \\
\hline & T3 & 68 & 81.0 \\
\hline & $\mathrm{T} 4$ & 5 & 6.0 \\
\hline \multirow[t]{2}{*}{$\mathrm{N}$ status } & No & 35 & 41.7 \\
\hline & N1 & 49 & 58.3 \\
\hline \multirow[t]{2}{*}{ Residual tumor ${ }^{a}$} & RO & 39 & 48.1 \\
\hline & $\mathrm{R} 1$ & 42 & 51.9 \\
\hline \multirow[t]{3}{*}{ Histological grading } & G1 & 2 & 2.4 \\
\hline & G2 & 28 & 33.3 \\
\hline & G3 & 54 & 64.3 \\
\hline \multirow[t]{3}{*}{ Perioperative therapy } & Chemotherapy & 5 & 6.0 \\
\hline & Chemoradiation & 49 & 58.3 \\
\hline & none & 30 & 35.7 \\
\hline
\end{tabular}

$P D$ partial pancreatoduodenectomy (Kausch-Whipple procedure), $P P P D$ pylorus preserving partial pancreatoduodenectomy (Traverso-Longmire procedure), $D P$ distal pancreatectomy, TP total pancreatectomy

${ }^{a}$ missing information on resection status in three patients and other clinicopathological parameters, such as sex, age, $\mathrm{T}$ and $\mathrm{N}$ stage, and histological grading. Furthermore, additional therapy (chemotherapy or chemoradiation) and ER expression did not correlate (Table 2). Interestingly, in adjacent normal pancreatic tissue, ER beta expression was detected in 41 patients (48.8\%). A downregulation of ER beta expression in tumor tissue, compared to normal tissue, as defined by a lower staining score, was seen in 42 cases (50.0\%).

\section{Univariate survival analysis}

Mean overall survival of all patients after resection of the primary tumor was 27.0 months $(95 \%$ confidence interval 22.3-31.6 months), and mean disease free survival was 21.2 months (95\% confidence interval 17.225.1 months). Patients with ER $\beta$ expressing tumors survived 16.6 months compared to 30.9 months in patients without ER $\beta$ expression ( $p=0.009$, Fig. 2a). Disease free survival was 13.5 months in patients with ER $\beta$ expression compared to 23.5 months in patients with no ER $\beta$ expression ( $p=0.037$, Fig. $2 \mathrm{~b})$. Overall survival in nodal positive patients was 21.5 months versus 33.1 months in nodal negative patients $(p=0.021$, Fig. 2a). Disease free survival was 18.5 months in nodal positive patients which was significantly shorter compared to 25.1 months in patients with negative nodal status ( $p=0.066$, Fig. $2 b)$. Details are given in Table 3 and Table 4 . In long term survivors (overall survival 24 months and more, $n=25$ ) ER $\beta$ expression was detected in $25 \%$, while patients who survived less than 12 months $(n=25)$ showed ER $\beta$ expression in $44 \%$ (Fig. 3, $p=0.0027$ ).

\section{Multivariate survival analysis}

To validate ER $\beta$ expression as an independent prognostic indicator in PDAC on overall survival, multivariate regression analysis was performed. Expression of ER $\beta$ was demonstrated to be an independent prognostic indicator of overall survival (hazard ratio 1.938, $p=0.047$ ). Of the remaining variables tested only positive nodal status showed a trend towards adverse survival however did not become statistically significant (hazard ratio $1.831, p=0.069$ ). Male sex and residual tumor status also failed to show statistical significance in the multivariate survival analysis. Details are shown in Table 5.

\section{Discussion}

In the present study, ER $\beta$ was expressed on PDAC in $31 \%$ of all patients. Expression of ER $\beta$ did not correlate with any of the clinicopathological parameters examined, however ER $\beta$ expression was strongly associated with an adverse overall survival and disease free survival in univariate analyses. Multivariate analysis showed that ER $\beta$ expression on tumor cells was an independent prognostic factors of overall survival. 

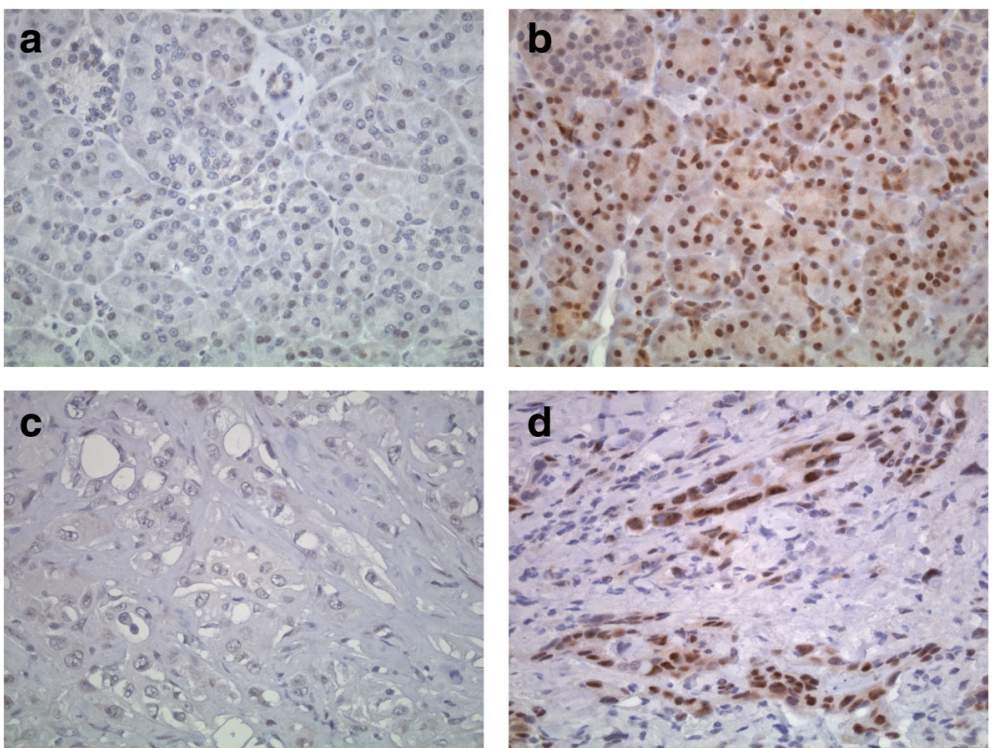

Fig. 1 Nuclear expression of estrogen receptor beta (ERß) in pancreatic ductal adenocarcinoma and corresponding normal tissue. Samples of nontumorous pancreatic tissue (upper panel) and corresponding pancreatic ductal adenocarcinoma (lower panel) without (a and $\mathbf{c}$ ) and with ER $\beta$ expression (b and $\mathbf{d}$ ) are shown. ERß immunohistochemistry, magnification 640× (a-d)

To our knowledge, this study is the largest series on expression of ER on pancreatic neoplasms. The fact that ER $\alpha$ is not detectable with immunohistochemical methods on PDAC tissue is concordant with several other smaller studies $[27,28]$. However, there are two studies which showed ER $\alpha$ expression on mRNA level on PDAC [29, 30]. Whether this finding reflects ER $\alpha$ protein levels being expressed in very small amounts not detectable with

Table 2 Correlation of estrogen receptor beta (ERß) expression with clinicopathological parameters

\begin{tabular}{lllll}
\hline Variable & & $n$ & ERß expression & $P$ value \\
\hline Total & & 84 & $26(31.0 \%)$ & \\
Sex & female & 43 & $16(37.2 \%)$ & 0.243 \\
Age & male & 41 & $10(24.4 \%)$ & \\
& $\leq 60$ years & 24 & $7(29.2 \%)$ & 1.000 \\
T status & $>60$ years & 60 & $19(31.7 \%)$ & \\
& $1-2$ & 11 & $3(27.3 \%)$ & 1.000 \\
N status & $3-4$ & 73 & $23(31.5 \%)$ & \\
& 0 & 35 & $11(31.4 \%)$ & 1.000 \\
Tumor grade & $1-2$ & 49 & $15(30.6 \%)$ & \\
& 3 & 30 & $7(23.3 \%)$ & 0.328 \\
Residual tumor & R0 & 54 & $19(35.2 \%)$ & \\
& R1 & 39 & $11(28.2 \%)$ & 0.487 \\
Perioperative & Surgery alone & 30 & $13(43.3 \%)$ & 0.086 \\
therapy & Chemoradiation/ & 54 & $13(24.1 \%)$ & \\
& Chemotherapy & & & \\
\hline
\end{tabular}

${ }^{a}$ missing information on resection status in three patients immunohistochemical methods, or a missing translation of $E R \alpha$ mRNA in PDAC is unknown. Interestingly, mucinous cystic tumors seem to express ER $\alpha$ more frequently than PDAC, possibly reflecting the "ovarian-type stroma" defining mucinous cystic tumors [31, 32]. Data on ER $\alpha$ expression in this entity is still pending.

ER $\beta$ was however expressed in nontumorous tissue, and to a lesser extent in the corresponding PDAC specimens. Compared to normal pancreatic tissue, an overall loss of ER $\beta$ expression in PDAC was detected in the majority of the investigated cases, suggesting ER $\beta$ loss as a molecular event in the line of tumor progression. Yet, the presence of ER $\beta$ expression in the tumor correlates with an adverse prognosis. This phenomenon may be explained by a crosstalk of ER $\beta$ signal transduction and other pathways that are activated during of tumor progression, leading to a more aggressive tumor phenotype in those subjects with an unchanged ER $\beta$ signaling pathway. In fact, non-ligand dependent ER signaling is well characterized. The ligand dependent pathway of ER signaling is initiated by steroid ligand binding to the ER. In the non-ligand dependent pathway, activated kinase growth factor receptors phosphorylate ER, leading to its activation [33-36]. Loss of ER $\beta$ expression during tumor progression was described in several other tumor entities $[6,37,38]$. Seemingly, interplay between ER $\beta$ expression and tissue specific distribution of growth factors may be important for subsequent tumor progression.

In colon cancer cell lines, ER $\beta$ was shown to be the predominant ER, whereas ER $\beta$ mRNA expression was a lot lower and similar to normal tissue [6]. Similar results 

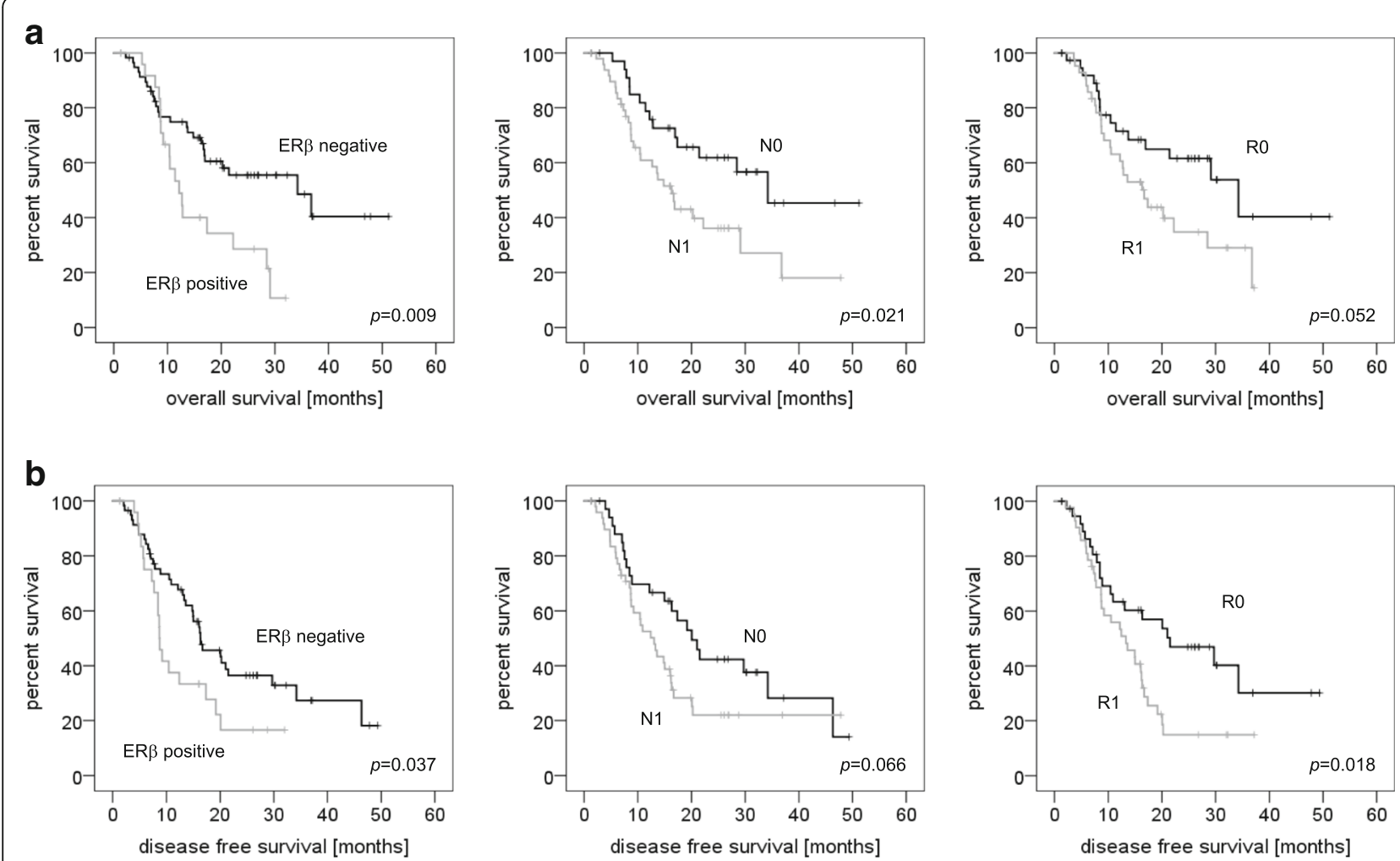

Fig. 2 Analysis of overall survival and disease free survival in 84 patients with resected pancreatic ductal adenocarcinoma

Table 3 Univariate analysis of prognostic factors for overall survival in resected pancreatic ductal adenocarcinoma

\begin{tabular}{|c|c|c|c|c|c|c|c|}
\hline \multirow{2}{*}{$\frac{\text { Variable }}{\text { Total }}$} & & \multirow{2}{*}{$\frac{\text { Mean OS [months] }}{27.0}$} & \multicolumn{3}{|c|}{$95 \% \mathrm{Cl}$} & \multirow{2}{*}{$\begin{array}{l}\text { Median OS [months] } \\
21.4\end{array}$} & \multirow[t]{2}{*}{$p$ value } \\
\hline & & & 22.3 & - & 31.6 & & \\
\hline \multirow[t]{2}{*}{ Sex } & female & 23.1 & 17.7 & - & 28.5 & 16.3 & 0.122 \\
\hline & male & 30.2 & 22.5 & - & 37.9 & 34.2 & \\
\hline \multirow[t]{2}{*}{ Age } & $\leq 60$ years & 29.4 & 21.6 & - & 37.1 & 21.4 & 0.398 \\
\hline & $>60$ years & 25.4 & 20.1 & - & 30.8 & 20.2 & \\
\hline \multirow[t]{2}{*}{ T status } & $\mathrm{T} 1-2$ & 26.2 & 15.2 & - & 37.2 & 17.0 & 0.969 \\
\hline & T3-4 & 26.8 & 21.8 & - & 31.9 & 22.2 & \\
\hline \multirow[t]{2}{*}{ N status } & No & 33.1 & 26.1 & - & 40.2 & 34.2 & 0.021 \\
\hline & $\mathrm{N} 1$ & 21.5 & 16.1 & - & 26.8 & 16.3 & \\
\hline \multirow[t]{2}{*}{ Tumor grading } & G1-2 & 28.1 & 21.3 & - & 34.9 & 36.8 & 0.228 \\
\hline & G3 & 25.3 & 19.6 & - & 31.0 & 16.7 & \\
\hline \multirow[t]{2}{*}{ Residual tumor } & RO & 31.4 & 24.0 & - & 38.8 & 34.2 & 0.052 \\
\hline & R1 & 19.8 & 15.7 & - & 23.9 & 16.7 & \\
\hline \multirow[t]{2}{*}{ ER $\beta$ expression } & negative & 30.9 & 25.2 & - & 36.7 & 34.2 & 0.009 \\
\hline & positive & 16.6 & 12.7 & - & 20.4 & 12.2 & \\
\hline Perioperative & CRT/CTX & 25.5 & 18.5 & & 32.5 & 17.4 & 0.800 \\
\hline therapy & none & 27.2 & 21.5 & & 32.9 & 21.4 & \\
\hline
\end{tabular}

Cl confidence interval, OS overall survival, CRT chemoradiotherapy, CTX chemotherapy 
Table 4 Univariate analysis of prognostic factors for disease free survival in resected pancreatic ductal adenocarcinoma

\begin{tabular}{|c|c|c|c|c|c|c|c|}
\hline \multirow{2}{*}{$\frac{\text { Variable }}{\text { Total }}$} & & \multirow{2}{*}{$\frac{\text { Mean DFS [months] }}{21.2}$} & \multicolumn{3}{|c|}{$95 \% \mathrm{Cl}$} & \multirow{2}{*}{$\begin{array}{l}\text { Median DFS [months] } \\
15.0\end{array}$} & \multirow[t]{2}{*}{$p$ value } \\
\hline & & & 17.2 & - & 25.1 & & \\
\hline \multirow[t]{2}{*}{ Sex } & female & 20.4 & 15.2 & - & 25.6 & 12.2 & 0.485 \\
\hline & male & 22.0 & 16.1 & - & 27.9 & 16.3 & \\
\hline \multirow[t]{2}{*}{ Age } & $\leq 60$ years & 22.4 & 15.0 & - & 29.8 & 16.1 & 0.704 \\
\hline & $>60$ years & 20.5 & 15.8 & - & 25.2 & 15.0 & \\
\hline \multirow[t]{2}{*}{ T status } & $\mathrm{T} 1-2$ & 25.6 & 13.5 & - & 37.7 & 16.3 & 0.701 \\
\hline & T3-4 & 20.7 & 16.4 & - & 25.0 & 15.0 & \\
\hline \multirow[t]{2}{*}{$\mathrm{N}$ status } & NO & 25.1 & 18.9 & - & 31.2 & 20.0 & 0.066 \\
\hline & $\mathrm{N} 1$ & 18.5 & 13.6 & - & 23.5 & 13.0 & \\
\hline \multirow[t]{2}{*}{ Tumor grading } & G1-2 & 24.4 & 17.3 & - & 31.6 & 20.1 & 0.293 \\
\hline & G3 & 19.5 & 14.8 & - & 24.1 & 14.8 & \\
\hline \multirow[t]{2}{*}{ Residual tumor } & RO & 25.9 & 19.4 & - & 32.5 & 21.5 & 0.018 \\
\hline & $\mathrm{R} 1$ & 15.1 & 11.7 & - & 18.5 & 13.3 & \\
\hline \multirow[t]{2}{*}{ ERß expression } & negative & 23.5 & 18.7 & - & 28.4 & 16.3 & 0.037 \\
\hline & positive & 13.5 & 9.6 & - & 17.4 & 8.7 & \\
\hline Perioperative & CRT/CTX & 21.4 & 16.5 & - & 26.3 & 15.0 & 0.800 \\
\hline therapy & none & 20.4 & 13.5 & - & 27.2 & 16.7 & \\
\hline
\end{tabular}

CI confidence interval, DFS disease free survival, CRT chemoradiotherapy, CTX chemotherapy

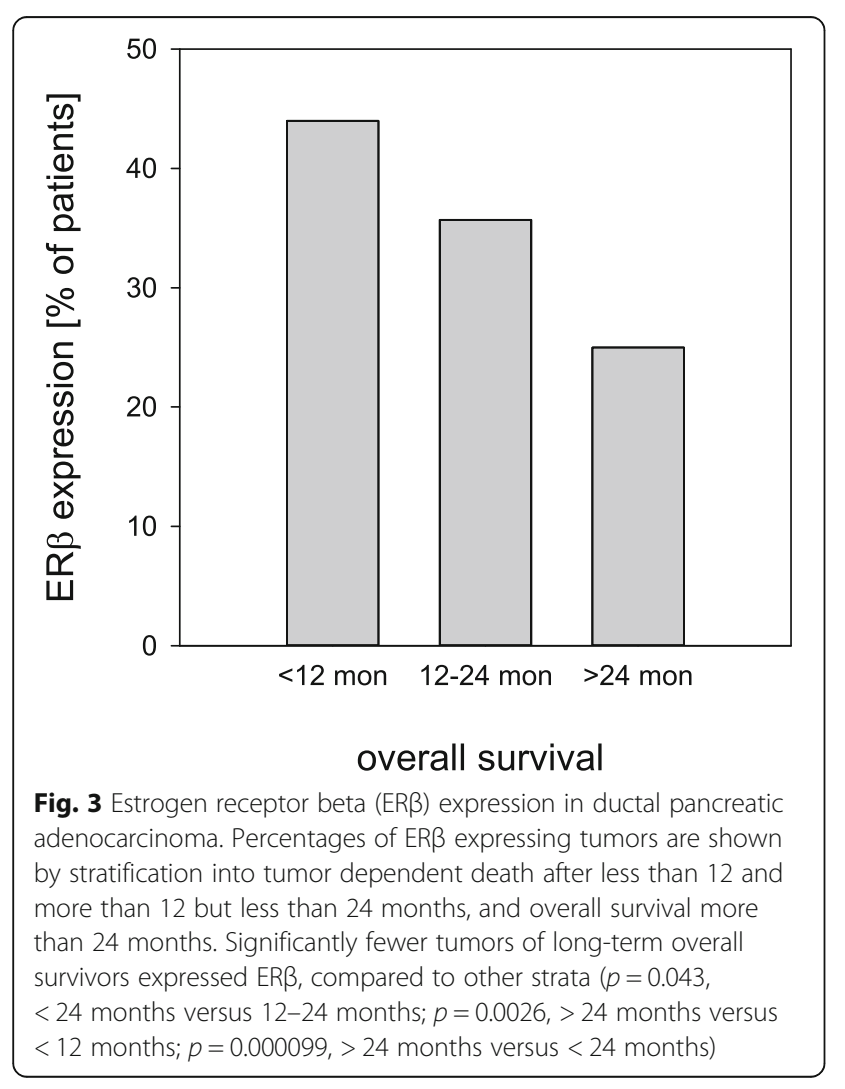

were obtained when examining ER $\beta$ expression in human tumor samples [37, 39].

No significant correlation was found between ER $\beta$ expression and clinicopathological features of patients and PDAC specimens. A trend was seen towards a lower ER $\beta$ expression in male patients, but statistical significance was not reached. Circulating estrogen levels may have some effect on ER $\beta$ expression. In fact, an upregulation of ER $\beta$ by estrogen has been described previously [40]. However, since the majority of the female patients in our cohort is postmenopausal, as reflected by age distribution, this effect must be regarded as questionable. Similarly, a trend was detected towards a higher expression of ER $\beta$ in less differentiated tumors, underlining a role of ER $\beta$ in tumor progression towards a more aggressive phenotype. This finding is supported by recent data in breast cancer, where ER $\beta$ expression was found to correlate with tumor grading and higher expression of the proliferation marker Ki-67 in women with ER $\alpha$ negative breast cancer [9]. Similarly, in esophageal cancer, a

Table 5 Multivariate analysis of prognostic factors for overall survival in pancreatic ductal adenocarcinoma

\begin{tabular}{llll}
\hline Parameter & Hazard ratio & $95 \% \mathrm{Cl}$ & $p$ value \\
\hline ERß expression & 1.938 & $1.010-3.720$ & 0.047 \\
$\mathrm{~N} 1$ & 1.831 & $0.954-3.517$ & 0.069 \\
Residual tumor & 1.704 & $0.894-3.247$ & 0.105 \\
Male sex & 0.628 & $0.355-1.311$ & 0.251 \\
\hline
\end{tabular}

$\mathrm{Cl}$ confidence interval 
correlation of ER $\beta$ expression with poor differentiation status and tumor stage was found in squamous cell carcinomas and in adenocarcinomas [41].

In the analyzed cohort, ER $\beta$ expression was found to strongly correlate with a reduction of overall survival and disease free survival in patients with resected pancreatic adenocarcinoma in univariate and multivariate analyses. Multivariate analysis of overall survival, revealed that the expression of ER $\beta$ is an independent negative prognostic factor. Patients with lymph node metastases had a shorter survival, although this did not reach statistical significance. Interestingly, resection status ( $\mathrm{R} 0$ versus $\mathrm{R} 1$ ) also failed to be a statistically significant prognostic factor of overall survival and disease free survival in the multivariate analysis. This finding may be partially explained by underestimation of the number of R1 resections [42], as examination of circumferential resection margin was not incorporated in routine pathological protocol when specimens were analyzed originally.

At present, clinical data on the impact of ER expression on solid tumors on survival except in breast cancer is not sufficient to establish a clear prognostic role of the different ER subtypes. In esophageal squamous cell carcinoma and gastric adenocarcinoma, expression of ER $\alpha$ in the absence of ER $\beta$ was described to correlate with an adverse prognosis [38, 43]. In colorectal cancer, loss of ER $\beta$ expression correlates with advanced cancer stages and poor survival [44]. In hepatocellular cancer, both ER $\alpha$ and ER $\beta$ are expressed [45]. Presence of a variant $\mathrm{ER} \alpha$ in hepatocellular carcinoma correlates with shorter survival, compared to wild type ER [46].

However, some clinical and experimental data support the hypothesis that ER $\beta$ expression may lead to a more aggressive tumor phenotype. In ER $\alpha$ negative breast cancer, ER $\beta$ expression correlates with an increased Ki-67 expression, suggesting a higher proliferation rate within the tumor cells. In the same cohort, ER $\beta$ expression positively correlated with advanced tumor grade [9]. Similar findings were described in sarcoma patients [11]. In vitro proliferation of non small cell lung cancer cells was reduced by siRNA mediated elimination of ER $\beta$ signaling [10]. In contrast, ER $\beta$ deficiency results in an enhanced tumorigenesis in the small bowel, but not in the colon of Apc $(\mathrm{min} /+)$ mice, suggesting a tumor suppressor effect of ER $\beta$ [47].

The exact role of ER signaling in solid tumors remains to be defined. Our data strongly suggest a tumor promoting role of ER $\beta$ signaling in PDAC, which is in line with previously published data on non small cell lung cancer $[21,48]$. However, there are studies showing an effect of ER $\beta$ on tumor suppression, especially in colon cancer [49-51]. These conflicting results may be explained by differences in the tissue distribution of the ER subtypes and their splicing variants. Moreover, ER signaling is embedded in a complex signaling network controlling tumor cell growth and proliferation to the effect that context specific signaling interactions lead to different effects in different tissue types [52]. In the present study, the phosphorylation status of ER $\beta$ was not examined. One can speculate that differences of tissue specific ER $\beta$ phosphorylation lead to differential ER mediated actions that are mediated by ligand independent ER signaling. Specifically, an extensive crosstalk between epidermal growth factor receptor (EGFR) and ER mediated pathways is well documented in several tumor types [40]. Since a strong EGFR expression is present in PDAC, ER phosphorylation by EGFR mediated growth signals and the resulting proliferative stimulus may be an important contributor to the adverse prognostic effects observed. In fact, EGFR inhibition combined with ER signaling disruption resulted in a marked inhibition of tumor xenograft growth [10].

A limitation of the present study is the different perioperative treatment of the patients included. In the cohort presented, $58 \%$ of the patients received perioperative chemoradiation. Although a clear survival benefit of perioperative chemoradiation in patients with resectable PDAC has not been shown [53], there is a possible impact of irradiation and/or chemotherapy on ER expression [54]. However, whether this is true for the ER $\beta$ subtype and is unknown, and its clinical significance remains unclear. To clarify this issue, additional studies may correlate the expression of ER $\beta$ on pretherapeutic tumor biopsies with the expression on surgical specimens after neoadjuvant therapy.

\section{Conclusions}

Here, the expression of ER $\beta$ was analyzed on surgical specimens of patients with PDAC and correlated with overall and disease free survival. ER $\beta$ was expressed on $31 \%$ of PDAC surgical specimens. A correlation between ER $\beta$ expression and an adverse prognosis in resected PDAC seems to exist. These data may be useful in defining a role of ER $\beta$ expression as a prognostic indicator and as a potential molecular target in patients with advanced PDAC.

\section{Abbreviations \\ Cl: Confidence interval; CRT: Chemoradiotherapy; CTX: Chemotherapy; DFS: Disease free survival; DP: Distal pancreatectomy; EGF: Epidermal growth factor; EGFR: Epidermal growth factor receptor; ER: Estrogen receptor; MAP kinase: Mitogen activated protein kinase; OS: Overall survival; PD: Partial pancreatoduodenectomy; PDAC: Pancreatic ductal adenocarcinoma; PPPD: pylorus preserving partial pancreatoduodenectomy; TMA: Tissue microarray; TP: Total pancreatectomy}

\section{Acknowledgements}

The authors thank Andrea Sendelhofert for excellent technical assistance in constructing and staining the tissue microarrays.

\section{Funding}

HS performed the study design, data collection, analysis and interpretation and wrote the manuscript while on a scientific rotation position funded by the Deutsche Forschungsgemeinschaft (DFG, KFO128). Further, the authors 
acknowledge support from the DFG and the Open Access Publication Fund of Charité - Universitätsmedizin Berlin.

\section{Availability of data and materials}

The datasets used and analysed during the study are available from the corresponding author on reasonable request.

\section{Authors' contributions}

HS and CJB designed the study. GA, TK, IP, and YZ constructed and analyzed the tissue microarray. $\mathrm{HS}, \mathrm{IP}$, and $\mathrm{YZ}$ collected and analyzed the clinicopathological and survival data. HS wrote the manuscript draft. MHM, MEK and CJB critically reviewed the manuscript. All authors read and approved the final manuscript.

\section{Ethics approval and consent to participate}

The study was approved by the Ethics Committee of the Hospital of the University of Munich. Due to the retrospective nature of the study, explicit consent was not required.

\section{Consent for publication}

Not applicable.

\section{Competing interests}

The authors declare that they have no competing interests.

\section{Publisher's Note}

Springer Nature remains neutral with regard to jurisdictional claims in published maps and institutional affiliations.

\begin{abstract}
Author details
'Department of General, Visceral and Vascular Surgery, Campus Benjamin Franklin, Charité Universitätsmedizin Berlin, corporate member of Freie Universität Berlin, Humboldt-Universität zu Berlin, and Berlin Institute of Health, D-12200 Berlin, Germany. ${ }^{2}$ Institute of Pathology,

Ludwig-Maximilians-University, D-80337 Munich, Germany. ${ }^{3}$ Department of General, Visceral and Transplantation Surgery, Hospital of the University of Munich, D-81377 Munich, Germany. ${ }^{4}$ Department of General, Visceral and Cancer Surgery, University of Cologne, D-50937 Cologne, Germany. ${ }^{5}$ Department of Minimal Invasive and Visceral Surgery, Vivantes Klinikum Neukölln, D-12351 Berlin, Germany.
\end{abstract}

Received: 13 April 2018 Accepted: 18 October 2018

Published online: 29 October 2018

\section{References}

1. Siegel RL, Miller KD, Jemal A. Cancer statistics, 2017. CA Cancer J Clin. 2017; 67(1):7-30.

2. Kamisawa T, Wood LD, Itoi T, Takaori K. Pancreatic cancer. Lancet. 2016; 388(10039):73-85.

3. Ryan DP, Hong TS, Bardeesy N. Pancreatic adenocarcinoma. New Engl J Med. 2014:371(11):1039-49.

4. Chiaravalli M, Reni M, O'Reilly EM. Pancreatic ductal adenocarcinoma: stateof-the-art 2017 and new therapeutic strategies. Cancer Treat Rev. 2017;60: 32-43.

5. Ottaiano A, Capozzi M, De Divitiis C, De Stefano A, Botti G, Avallone A, Tafuto S. Gemcitabine mono-therapy versus gemcitabine plus targeted therapy in advanced pancreatic cancer: a meta-analysis of randomized phase III trials. Acta Oncol. 2017;56(3):377-83.

6. Campbell-Thompson M, Lynch IJ, Bhardwaj B. Expression of estrogen receptor (ER) subtypes and ERbeta isoforms in colon cancer. Cancer Res. 2001;61(2):632-40

7. Martineti V, Picariello L, Tognarini I, Carbonell Sala S, Gozzini A, Azzari C, Mavilia C, Tanini A, Falchetti A, Fiorelli $G$, et al. ERbeta is a potent inhibitor of cell proliferation in the HCT8 human colon cancer cell line through regulation of cell cycle components. Endocr Relat Cancer. 2005;12(2):455-69.

8. Satake M, Sawai H, Go VL, Satake K, Reber HA, Hines OJ, Eibl G. Estrogen receptors in pancreatic tumors. Pancreas. 2006;33(2):119-27.

9. Skliris GP, Leygue E, Curtis-Snell L, Watson PH, Murphy LC. Expression of oestrogen receptor-beta in oestrogen receptor-alpha negative human breast tumours. Br J Cancer. 2006;95(5):616-26.
10. Marquez-Garban DC, Chen HW, Fishbein MC, Goodglick L, Pietras RJ. Estrogen receptor signaling pathways in human non-small cell lung cancer. Steroids. 2007;72(2):135-43.

11. Greenberg JA, Somme S, Russnes HE, Durbin AD, Malkin D. The estrogen receptor pathway in rhabdomyosarcoma: a role for estrogen receptor-beta in proliferation and response to the antiestrogen $4^{\prime} \mathrm{OH}$-tamoxifen. Cancer Res. 2008;68(9):3476-85

12. Taylor OM, Benson EA, McMahon MJ. Clinical trial of tamoxifen in patients with irresectable pancreatic adenocarcinoma. The Yorkshire Gastrointestinal Tumour Group. Br J Surg. 1993;80(3):384-6.

13. Tomao S, Romiti A, Massidda B, lonta MT, Farris A, Zullo A, Brescia A, Santuari L, Frati L. A phase II study of gemcitabine and tamoxifen in advanced pancreatic cancer. Anticancer Res. 2002;22(4):2361-4.

14. Wong A, Chan A. Survival benefit of tamoxifen therapy in adenocarcinoma of pancreas. A case-control study. Cancer. 1993;71(7):2200-3.

15. Mosselman S, Polman J, Dijkema R. ER beta: identification and characterization of a novel human estrogen receptor. FEBS Lett. 1996;392(1):49-53.

16. Kuiper GG, Gustafsson JA. The novel estrogen receptor-beta subtype: potential role in the cell- and promoter-specific actions of estrogens and anti-estrogens. FEBS Lett. 1997;410(1):87-90.

17. Paech K, Webb P, Kuiper GG, Nilsson S, Gustafsson J, Kushner PJ, Scanlan TS. Differential ligand activation of estrogen receptors ERalpha and ERbeta at AP1 sites. Science. 1997:277(5331):1508-10.

18. Kuiper GG, Carlsson B, Grandien K, Enmark E, Haggblad J, Nilsson S, Gustafsson JA. Comparison of the ligand binding specificity and transcript tissue distribution of estrogen receptors alpha and beta. Endocrinology. 1997;138(3):863-70.

19. Gruvberger-Saal SK, Bendahl PO, Saal LH, Laakso M, Hegardt C, Eden P, Peterson C, Malmstrom P, Isola J, Borg A, et al. Estrogen receptor beta expression is associated with tamoxifen response in ERalpha-negative breast carcinoma. Clin Cancer Res. 2007;13(7):1987-94.

20. Hopp TA, Weiss HL, Parra IS, Cui Y, Osborne CK, Fuqua SA. Low levels of estrogen receptor beta protein predict resistance to tamoxifen therapy in breast cancer. Clin Cancer Res. 2004;10(22):7490-9.

21. Skjefstad K, Grindstad T, Khanehkenari MR, Richardsen E, Donnem T, Kilvaer T, Andersen S, Bremnes RM, Busund LT, Al-Saad S. Prognostic relevance of estrogen receptor alpha, beta and aromatase expression in non-small cell lung cancer. Steroids. 2016;113:5-13.

22. Ma L, Zhan P, Liu Y, Zhou Z, Zhu Q, Miu Y, Wang X, Jin J, Li Q, Lv T, et al. Prognostic value of the expression of estrogen receptor beta in patients with non-small cell lung cancer: a meta-analysis. Transl Lung Cancer Res. 2016;5(2):202-7.

23. Song RX, Zhang Z, Chen Y, Bao Y, Santen RJ. Estrogen signaling via a linear pathway involving insulin-like growth factor I receptor, matrix metalloproteinases, and epidermal growth factor receptor to activate mitogen-activated protein kinase in MCF-7 breast cancer cells. Endocrinology. 2007;148(8):4091-101.

24. Konduri S, Schwarz RE. Estrogen receptor beta/alpha ratio predicts response of pancreatic cancer cells to estrogens and phytoestrogens. J Surg Res. 2007;140(1):55-66

25. Kononen J, Bubendorf L, Kallioniemi A, Barlund M, Schraml P, Leighton S, Torhorst J, Mihatsch MJ, Sauter G, Kallioniemi OP. Tissue microarrays for high-throughput molecular profiling of tumor specimens. Nat Med. 1998; 4(7):844-7.

26. Remmele W, Stegner HE. Recommendation for uniform definition of an immunoreactive score (IRS) for immunohistochemical estrogen receptor detection (ER-ICA) in breast cancer tissue. Pathologe. 1987;8(3):138-40.

27. Ollayos CW, Riordan GP, Rushin JM. Estrogen receptor detection in paraffin sections of adenocarcinoma of the colon, pancreas, and lung. Arch Pathol Lab Med. 1994;118(6):630-2.

28. Yeh TS, Jan YY, Chiu CT, Ho YB, Chen TC, Lee KF, Chan KM, Hsu JC, Hwang TL, Chen MF. Characterisation of oestrogen receptor, progesterone receptor, trefoil factor 1, and epidermal growth factor and its receptor in pancreatic cystic neoplasms and pancreatic ductal adenocarcinoma. Gut. 2002;51(5):712-6.

29. Iwao K, Miyoshi Y, Ooka M, Ishikawa O, Ohigashi H, Kasugai T, Egawa C, Noguchi S. Quantitative analysis of estrogen receptor-alpha and -beta messenger RNA expression in human pancreatic cancers by real-time polymerase chain reaction. Cancer Lett. 2001;170(1):91-7.

30. Singh S, Baker PR, Poulsom R, Wright NA, Sheppard MC, Langman MJ, Neoptolemos JP. Expression of oestrogen receptor and oestrogen-inducible genes in pancreatic cancer. Br J Surg. 1997:84(8):1085-9. 
31. Izumo A, Yamaguchi K, Eguchi T, Nishiyama K, Yamamoto H, Yonemasu H, Yao T, Tanaka M, Tsuneyoshi M. Mucinous cystic tumor of the pancreas: immunohistochemical assessment of "ovarian-type stroma". Oncol Rep. 2003;10(3):515-25.

32. Thompson LD, Becker RC, Przygodzki RM, Adair CF, Heffess CS. Mucinous cystic neoplasm (mucinous cystadenocarcinoma of low-grade malignant potential) of the pancreas: a clinicopathologic study of 130 cases. Am J Surg Pathol. 1999:23(1):1-16.

33. Arpino G, Wiechmann L, Osborne CK, Schiff R. Crosstalk between the estrogen receptor and the HER tyrosine kinase receptor family: molecular mechanism and clinical implications for endocrine therapy resistance. Endocr Rev. 2008;29(2):217-33.

34. Campbell RA, Bhat-Nakshatri P, Patel NM, Constantinidou D, Ali S, Nakshatri H. Phosphatidylinositol 3-kinase/AKT-mediated activation of estrogen receptor alpha: a new model for anti-estrogen resistance. J Biol Chem. 2001; 276(13):9817-24.

35. Heldring N, Pike A, Andersson S, Matthews J, Cheng G, Hartman J, Tujague M, Strom A, Treuter E, Warner M, et al. Estrogen receptors: how do they signal and what are their targets. Physiol Rev. 2007:87(3):905-31.

36. Shupnik MA. Crosstalk between steroid receptors and the c-Src-receptor tyrosine kinase pathways: implications for cell proliferation. Oncogene. 2004; 23(48):7979-89.

37. Konstantinopoulos PA, Kominea A, Vandoros G, Sykiotis GP, Andricopoulos P, Varakis I, Sotiropoulou-Bonikou G, Papavassiliou AG. Oestrogen receptor beta (ERbeta) is abundantly expressed in normal colonic mucosa, but declines in colon adenocarcinoma paralleling the tumour's dedifferentiation. Eur J Cancer. 2003;39(9):1251-8.

38. Nozoe T, Oyama T, Takenoyama M, Hanagiri T, Sugio K, Yasumoto K. Significance of immunohistochemical expression of estrogen receptors alpha and beta in squamous cell carcinoma of the esophagus. Clin Cancer Res. 2007;13(14):4046-50.

39. Slattery ML, Sweeney C, Murtaugh M, Ma KN, Wolff RK, Potter JD, Caan BJ, Samowitz W. Associations between ERalpha, ERbeta, and AR genotypes and colon and rectal cancer. Cancer Epidemiol Biomark Prev. 2005;14(12):2936-42.

40. Caiazza F, Galluzzo P, Lorenzetti S, Marino M. 17Beta-estradiol induces ERbeta up-regulation via p38/MAPK activation in colon cancer cells. Biochem Biophys Res Commun. 2007;359(1):102-7.

41. Kalayarasan R, Ananthakrishnan N, Kate V, Basu D. Estrogen and progesterone receptors in esophageal carcinoma. Dis Esophagus. 2008;21(4):298-303.

42. Verbeke CS, Menon KV. Variability in reporting resection margin status in pancreatic cancer. Ann Surg. 2008;247(4):716-7.

43. Xu CY, Guo JL, Jiang ZN, Xie SD, Shen JG, Shen JY, Wang LB. Prognostic role of estrogen receptor alpha and estrogen receptor beta in gastric cancer Ann Surg Oncol. 2010;17(9):2503-9.

44. Rudolph A, Toth C, Hoffmeister M, Roth W, Herpel E, Jansen L, Marx A, Brenner $\mathrm{H}$, Chang-Claude J. Expression of oestrogen receptor beta and prognosis of colorectal cancer. Br J Cancer. 2012;107(5):831-9.

45. lavarone M, Lampertico P, Seletti C, Francesca Donato M, Ronchi G, del Ninno E, Colombo M. The clinical and pathogenetic significance of estrogen receptor-beta expression in chronic liver diseases and liver carcinoma. Cancer. 2003;98(3):529-34.

46. Villa E, Colantoni A, Camma C, Grottola A, Buttafoco P, Gelmini R, Ferretti I, Manenti F. Estrogen receptor classification for hepatocellular carcinoma: comparison with clinical staging systems. J Clin Oncol. 2003;21(3):441-6.

47. Giroux V, Lemay F, Bernatchez G, Robitaille Y, Carrier JC. Estrogen receptor beta deficiency enhances small intestinal tumorigenesis in ApcMin/+ mice. Int J Cancer. 2008;123(2):303-11.

48. Fan S, Liao Y, Liu C, Huang Q, Liang H, Ai B, Fu S, Zhou S. Estrogen promotes tumor metastasis via estrogen receptor beta-mediated regulation of matrix-metalloproteinase-2 in non-small cell lung cancer. Oncotarget. 2017:8(34):56443-59.

49. Niv Y. Estrogen receptor beta expression and colorectal cancer: a systematic review and meta-analysis. Eur J Gastroenterol Hepatol. 2015;27(12):1438-42.

50. Stevanato Filho PR, Aguiar Junior S, Begnami MD, Ferreira FO, Nakagawa WT, Spencer R, Bezerra TS, Boggiss PE, Lopes A. Estrogen receptor beta as a prognostic marker of tumor progression in colorectal Cancer with familial adenomatous polyposis and sporadic polyps. Pathol Oncol Res. 2017;24(3):533-40.

51. Topi G, Ehrnstrom R, Jirstrom K, Palmquist I, Lydrup ML, Sjolander A. Association of the oestrogen receptor beta with hormone status and prognosis in a cohort of female patients with colorectal cancer. Eur J Cancer. 2017:83:279-89.
52. Miller MM, McMullen PD, Andersen ME, Clewell RA. Multiple receptors shape the estrogen response pathway and are critical considerations for the future of in vitro-based risk assessment efforts. Crit Rev Toxicol. 2017:47(7):564-80.

53. Assifi MM, Lu X, Eibl G, Reber HA, Li G, Hines OJ. Neoadjuvant therapy in pancreatic adenocarcinoma: a meta-analysis of phase II trials. Surgery. 2011; 150(3):476-3.

54. Torlakovic E, Lilleby W, Berner A, Torlakovic G, Chibbar R, Furre T, Fossa SD. Differential expression of steroid receptors in prostate tissues before and after radiation therapy for prostatic adenocarcinoma. Int J Cancer. 2005; 117(3):381-6.
Ready to submit your research? Choose BMC and benefit from:

- fast, convenient online submission

- thorough peer review by experienced researchers in your field

- rapid publication on acceptance

- support for research data, including large and complex data types

- gold Open Access which fosters wider collaboration and increased citations

- maximum visibility for your research: over $100 \mathrm{M}$ website views per year

At BMC, research is always in progress.

Learn more biomedcentral.com/submissions 